\title{
LITHOLOGICAL DIFFERENCES IN THE DEPOSITS OF CLOSED BASINS IN THE UPPER PARSĘTA CATCHMENT (WESTERN POMERANIA)
}

\author{
Maciej Major \\ Adam Mickiewicz University, Institute of Geoecology and Geoinformation, Poznań, Poland
}

Manuscript received: June 25, 2010

Revised version: February 25, 2011

\begin{abstract}
Major M., 2011. Lithological differences in the deposits of closed basins in the upper Parsęta catchment (Western Pomerania). Quaestiones Geographicae 30(1), Bogucki Wydawnictwo Naukowe, Poznań, pp. 69-76, 3 Figs., 1 Tab. ISBN 978-83-62662-39-5. ISSN 0137-477X. DOI 10.2478/v10117-011-0006-0.
\end{abstract}

ABSTRACT. Basins without outlets, found in abundance in West Pomerania, display a great lithological diversity. Differences in the lithology in the upper Parsęta catchment result from the processes of areal deglaciation during the Vistulian Glaciation (Karczewski 1989). Intraglacial accumulation, action by fluvioglacial water, and direct glacial accumulation have produced various sedimentary series and their mosaic-like pattern. The youngest sedimentary series have developed during fluvial, aeolian and organogenic accumulation (Kostrzewski et al. 1994a). The lithology of most of the closed basins in the catchment largely features fine diamictic sands which pass into sandy diamicton at $100 \mathrm{~cm}$, then medium diamictic sands which turn into fine sands at depths of 50 and $100 \mathrm{~cm}$, and massive diamictic sands which turn again into sandy diamicton at $100 \mathrm{~cm}$. In the catchment of a closed evapotranspiration basin equipped with measuring instruments, the predominant deposit is sands, especially medium-grained ones. Much less abundant are diamictic sands and sandy diamictons, and silts occur only sporadically. Such a lithological diversity is responsible for different rates of the water cycle recorded in the particular parts of the study area.

KEYWORDS: lithological differences, upper Parsęta catchment, closed basins, grain-size indices

Maciej Major, Adam Mickiewicz University, Institute of Geoecology and Geoinformation, Dziegielowa 27, 61-680

Poznań, Poland, e-mail: maciej.major@amu.edu.pl

\section{Introduction}

Basins without outlets are a permanent element of the landscape of the postglacial zone within the temperate zone; they occupy a substantial proportion of the area. They can be found in abundance in West Pomerania.

For more than ten years a research has been carried out in the upper Parsęta catchment located in this region aiming to identify the properties and operation of geoecosystems of basins without outlets on the basis of the water cycle. The water cycle system in the catchments of such basins in a postglacial area is a carrier of dissolved matter and determines their operation. The effects are reflected in their soil covers and lithology.

The initial hypothesis adopted was that lithological differences were responsible for the different water cycle rates recorded in the particular parts of the study area. In some catchments without outlets or their parts, the lithology favours a quick response to precipitation and accelerates 
the rate of water circulation, while in other ones it slows the circulation down and favours water retention. That is why one of the stages of the research was a study of the lithological differences in deposits and their characteristics in the many closed depressions, which is intended to provide a background for later publications concerning a proper interpretation of hydrological processes occurring in small catchments without a surface runoff.

\section{Study area}

The research was conducted in the upper Parsęta catchment (Fig. 1), a geoecosystem of a lowland, postglacial area situated in the temperate zone and representative of the Pomerania region (Kostrzewski \& Zwoliński 1990, 1992, Kostrzewski et al. 1994a).

Displaying a marked relative relief, it extends on the northern slope of the Central Pomeranian end-morainic series within the so-called Parsęta lobe. Its relief results from complex deglaciation during the Pomeranian Stage of the Vistulian and during the Holocene morphogenetic cycle (Karczewski 1985, 1989). The basic part of the catchment is located within the outer subzone of the dead-ice moraine and kame moraine (Karczewski 1989; Kostrzewski et al. 1994a).

In the catchment, surface deposits include glacial tills, sands and gravels, as well as slope and mineral-organic deposits. Agriculture and forestry are the predominant land uses, while the soils are mostly brown with an admixture of black soils, muds, as well as mineral-organic and organic soils. The upper Parsęta catchment occupies an area of $74.0 \mathrm{~km}^{2}$, and the river has a length of $13.26 \mathrm{~km}$. Basins without outlets have a special place in the contemporary denudation system of the upper Parsęta catchment; they display a variety of genesis, sizes, morpholithology, and location (with respect to other landforms). They formed in the Late Glacial period, and in today's landscape most of them are water bodies (Kostrzewski et al. 1994b).

One of such basins (of a closed evapotranspiration type) characteristic of the postglacial

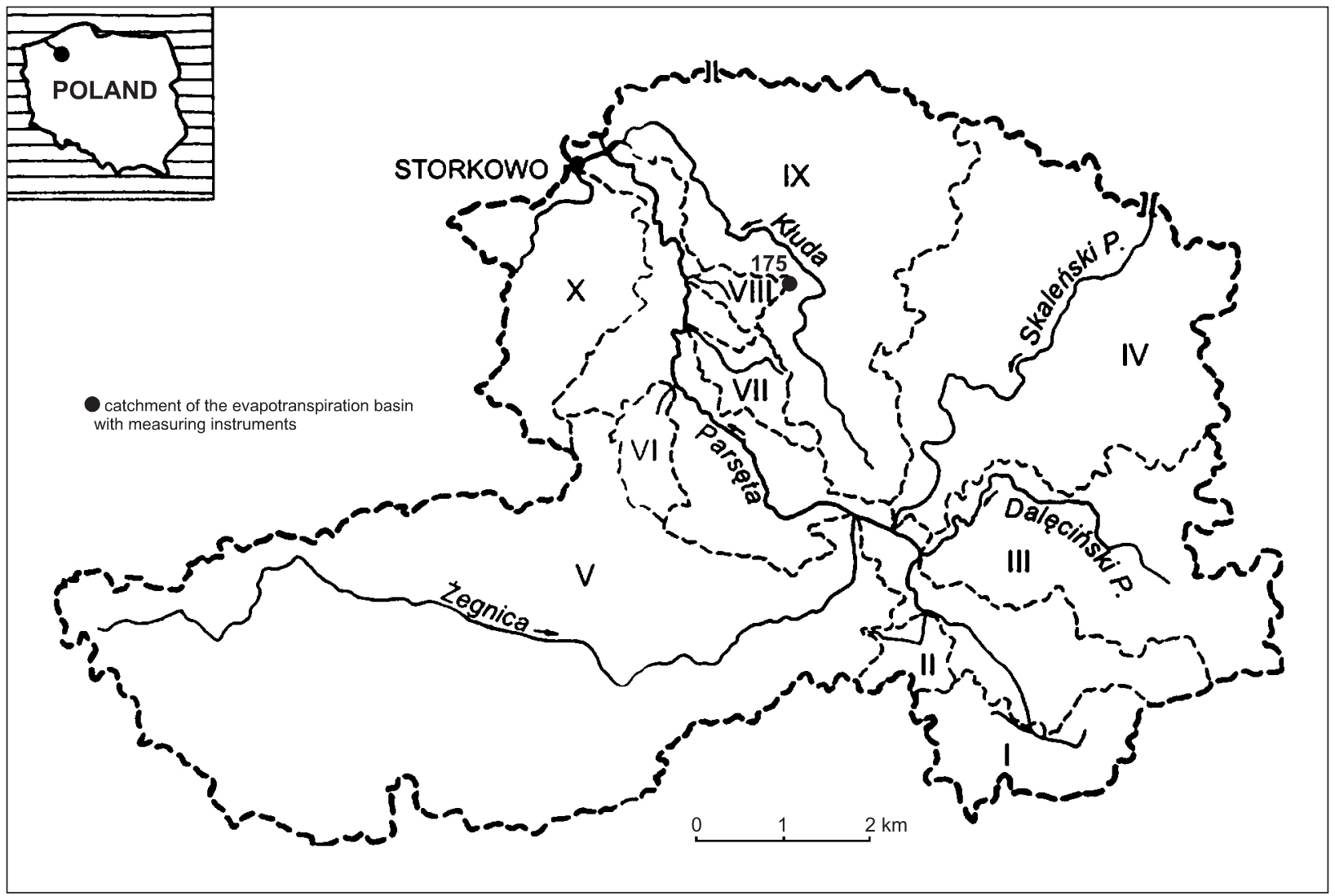

Fig. 1. Upper Parsęta catchment (after Kostrzewski et al. 1994a, modified) 
zone has been adjusted to detailed fieldwork and equipped with measuring instruments (Major 2009).

\section{Study methods}

The basic assumption underlying the present research was the conception put forward by Drwal (1975) in which areas without an outlet are divided by their water cycle mechanism into two groups: an evapotranspiration type with kettle ponds located at the bottom, and a water-absorbing type. On this basis a total of 357 closed basins were identified in the upper Parsęta catchment, of which 180 were of an absorptive type and 177 were an evapotranspiration type (Major 2009).

The study of lithological differences among all the closed basins identified in the upper Parsęta catchment was carried out on the basis of a lithological map of the area (Kostrzewski et al. 1994a).

In turn, to identify pedological and lithological differences in the catchment of the closed evapotranspiration basin equipped with measuring instruments, detailed fieldwork was carried out. Deposits were sampled during drilling when six piezometers were being installed along its W-E

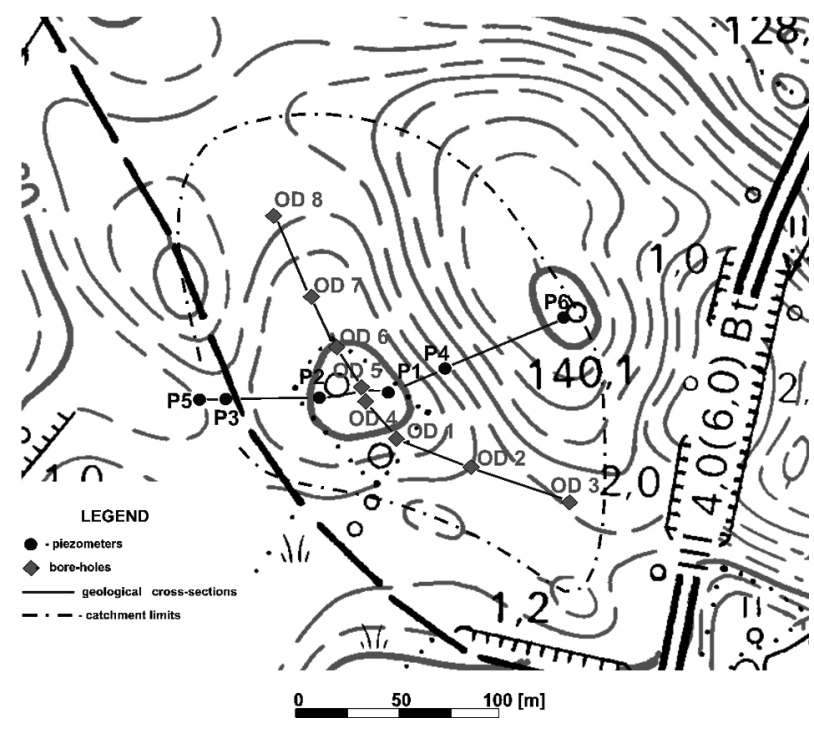

Fig. 2. Catchment of the evapotranspiration basin with measuring instruments

Source: Topographic map 1:10,000, sheet 333312 Radomyśl; topographic work 1986: Państwowe Przedsiębiorstwo GeodezyjnoKartograficzne in Warsaw, cartographic work 1989: Okręgowe Przedsiębiorstwo Geodezyjno-Kartograficzne in Cracow; modified after Major (2009). axis and from eight bore-holes drilled in the catchment of the basin along the N-S axis (Fig. 2). Most of the bore-holes were made with a hand-held drill. The maximum depth from which deposits were sampled was $8.8 \mathrm{~m}$ below ground level. The deposits were then subjected to detailed analyses in the Sedimentological Laboratory of the AMU Institute of Geoecology and Geoinformation in Poznań, where determinations were made of their mechanical composition by fraction and granulometric group following the Polish Norm PN-R-04033.

For the determinations, use was made of the widely employed sieve method and the Casagrande areometric method as modified by Prószyński (Dzięciołowski 1980). The final stage in the study of the lithology of deposits filling the closed basins was indoor work involving the calculation of graphic grain-size indices according to Folk \& Ward (1957), including mean grain diameter $(\mathrm{Mz})$, standard deviation $(\delta)$, skewness (Sk), and kurtosis (Kg).

\section{Lithology of the upper Parsęta catchment}

Differences in the lithology of the upper Parsęta catchment result from the processes of areal deglaciation during the Vistulian Glaciation (Karczewski 1989). Intraglacial accumulation, action by fluvioglacial water, and direct glacial accumulation have produced various sedimentary series and their mosaic-like pattern. The youngest sedimentary series developed during fluvial, aeolian and organogenic accumulation (Kostrzewski et al. 1994a).

According to Kostrzewski et al. (1994a), the largest area in the upper Parsęta catchment is occupied by deposits of direct ice-sheet accumulation, namely brown morainic tills, sometimes very high in sand content (Fig. 3).

Sands and gravels of fluvioglacial origin can be found in the north-eastern and middle parts of the upper Parsęta catchment. Tills of the endmorainic zone and varigrained deposits of kame terraces are much less frequent.

In the lower reaches of the upper Parsęta one can meet deposits of direct fluvial accumulation represented by alluvial deposits as well as strati- 

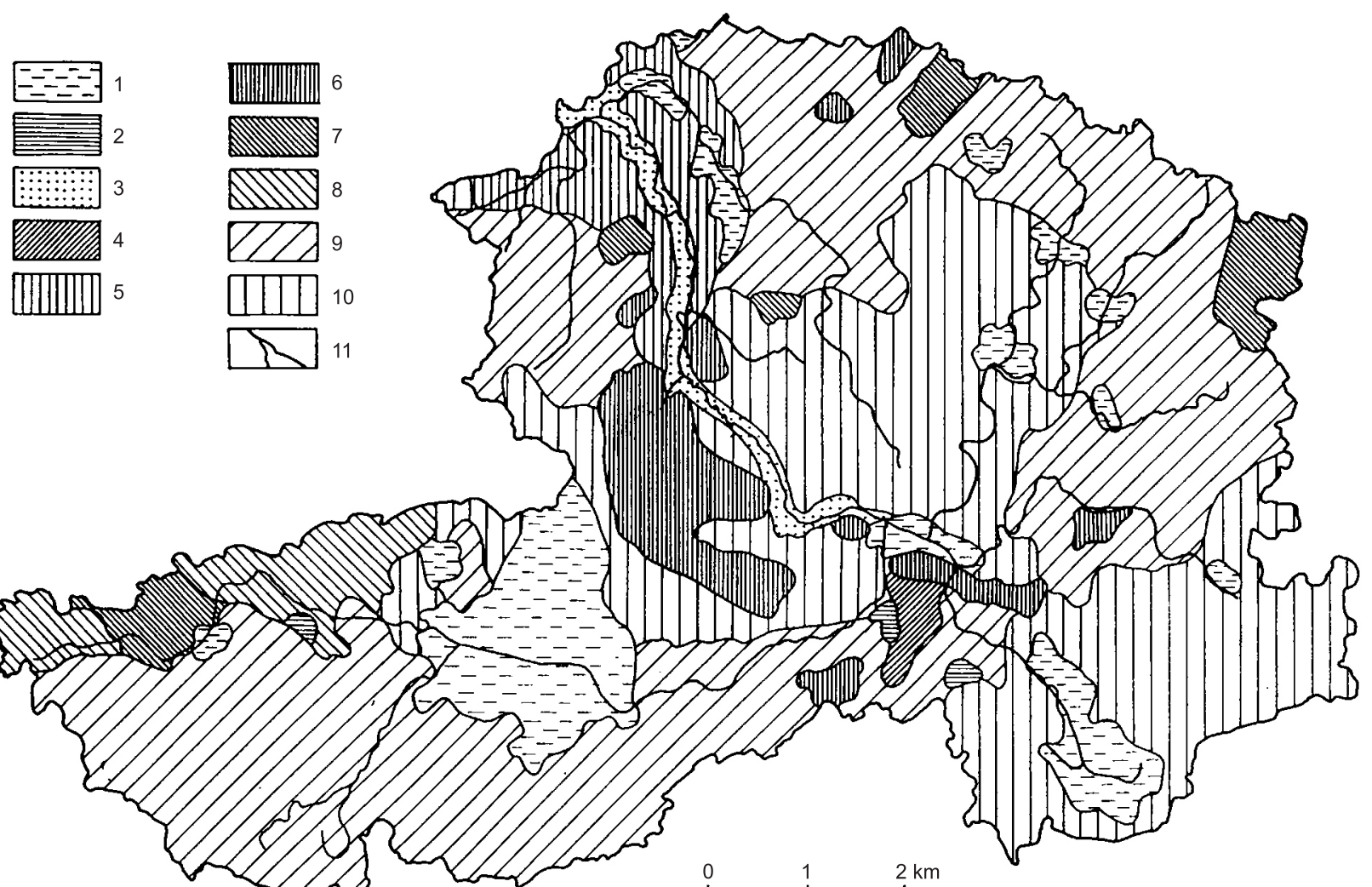

Fig. 3. Lithology of the upper Parsęta catchment (Kostrzewski et al. 1994a)

fied sands and gravels of older terrace levels. Deposits of aeolian origin have formed in fragments within the range of occurrence of fluvioglacial and fluvial deposits (Kostrzewski et al. 1994a).

A direct effect on physico-chemical properties of water is exerted by zones of organogenic deposits. The melt-out depressions of varying sizes that have developed as a result of melting of dead-ice blocks were first filled with mineral deposits - fine-grained sands and silts, and then by organogenic deposits - gyttjas and peats. Within the headwater area of the Parsęta, one can also find organogenic deposits like peat and carbonate gyttja. Peats and alluvial deposits also occur in basin-like widenings of stream valleys (Kostrzewski et al. 1994a).

\section{Lithology of closed basins}

Predominant in the lithology of the majority of closed basins in the upper Parsęta catchment are fine diamictic sands (SD) which pass into sandy diamicton (DS) at a depth of $100 \mathrm{~cm}(20.6 \%$ of basins), followed by medium diamictic sands
(Ss) which change into fine sands (SF) at depths of 50 and $100 \mathrm{~cm}(17.7 \%$ and $17.3 \%$, respectively), and massive diamictic sands (SDmm) transforming into sandy diamicton (DS) at $100 \mathrm{~cm} \mathrm{(16.0 \% )}$ (Table 1).

The lithology of closed evapotranspiration basins looks similarly. In turn, in closed absorptive basins the sequence is somewhat different. The highest proportion is contributed by medium diamictic sands (Ss) which turn into fine sands (SF) at depths of 50 and $100 \mathrm{~cm}(27.2 \%$ and $19.2 \%$ of basins, respectively), followed by massive diamictic sands (SDmm) that pass into sandy diamicton (DS) at $100 \mathrm{~cm}(16.8 \%)$, and diamictic sands (SD) changing into sandy diamicton (DS) at $100 \mathrm{~cm}(11.2 \%)$.

\section{Diversity of deposits in the instrument-equipped catchment of a closed basin}

Sand deposits predominate in the cross-section along the $\mathrm{W}-\mathrm{E}$ axis of the instrument-equipped catchment of a closed evapotranspiration basin, 
Table 1. Lithology of closed basins (Major 2009)

\begin{tabular}{|c|c|c|c|c|c|c|}
\hline \multirow{2}{*}{ Deposit } & \multicolumn{2}{|c|}{ Absorptive basins } & \multicolumn{2}{|c|}{ Evapotranspiration basins } & \multicolumn{2}{|c|}{ Total } \\
\hline & Number & $\%$ & Number & $\%$ & Number & $\%$ \\
\hline DS & 2 & 1.6 & - & - & 2 & 0.8 \\
\hline Fm & 10 & 8.0 & 8 & 6.8 & 18 & 7.4 \\
\hline Fm:SF & 1 & 0.8 & 4 & 3.4 & 5 & 2.1 \\
\hline SD & 2 & 1.6 & 9 & 7.6 & 11 & 4.5 \\
\hline SD.DS & - & - & 1 & 0.8 & 1 & 0.4 \\
\hline SD.Ss & - & - & 1 & 0.8 & 1 & 0.4 \\
\hline SD.GS & 2 & 1.6 & - & - & 2 & 0.8 \\
\hline SD:DS & 14 & 11.2 & 36 & 30.5 & 50 & 20.6 \\
\hline SD:SF & 1 & 0.8 & - & - & 1 & 0.4 \\
\hline SD:Ss & 7 & 5.6 & 4 & 3.4 & 11 & 4.5 \\
\hline SDmm & 1 & 0.8 & - & - & 1 & 0.4 \\
\hline $\mathrm{SDmm} \cdot \mathrm{DS}$ & 1 & 0.8 & 7 & 5.9 & 8 & 3.3 \\
\hline SDmm·DSF & - & - & 1 & 0.8 & 1 & 0.4 \\
\hline $\mathrm{SDmm} \cdot \mathrm{Ss}$ & - & - & 1 & 0.8 & 1 & 0.4 \\
\hline SDmm:DS & 21 & 16.8 & 18 & 15.2 & 39 & 16.0 \\
\hline SDmm:Ss & 1 & 0.8 & - & - & 1 & 0.4 \\
\hline SDmm:G & 3 & 2.4 & - & - & 3 & 1.2 \\
\hline $\mathrm{F}$ & 1 & 0.8 & 1 & 0.8 & 2 & 0.8 \\
\hline Ss.SF & 34 & 27.2 & 9 & 7.6 & 43 & 17.7 \\
\hline Ss:SF & 24 & 19.2 & 18 & 15.2 & 42 & 17.3 \\
\hline Total & 125 & 100.0 & 118 & 100.0 & 243 & 100.0 \\
\hline
\end{tabular}

Source: A lithological map of the upper Parsęta catchment (Kostrzewski et al. 1994a); symbols, Miall (1978).

- - vertical change of deposit at a depth of $50 \mathrm{~cm}$

: - vertical change of deposit at a depth of $100 \mathrm{~cm}$

in places where piezometers have been installed, on tops, and in the mid-slopes (Major 2009).

In the top parts of the afforested western section of the catchment near the watershed zone (P5) there appear fine-grained sands. Mediumgrained sands located lower display a similar granulometric composition. At a depth of about $650 \mathrm{~cm}$ b.g.l., medium diamictic sands can be found. At the next site in mid-slope, at the margin of woodland (P3), medium-grained sands are interbedded with medium diamictic sands at a depth of some $100 \mathrm{~cm}$ b.g.l. In the bottom part of the profile there appear finer deposits: finegrained sands and silts.

On the other side of the catchment, on top of the slope in the eastern part (P6), there are sands in the entire profile that are medium-grained in the upper part and pass into coarse-grained with depth. This situation is favourable to infiltration and subsurface flows, which was corroborated by a study of the water cycle. In the nearby midslope locality (P4), sands are interbedded with medium diamictic sands. Those are mostly medium-grained deposits.
In the bore-holes drilled on the margins of the depression, on both sides of the kettle pond (P1 and P2), the granulometric composition is highly diversified. The top layer is made up of sandy diamicton that pass into medium diamictic sands and diamictic sands. Those are medium- and fine-grained deposits. At depths greater than 65 $\mathrm{cm}$ b.g.l., there appear medium- and fine-grained sands.

Visible in the cross-section along the N-S axis is a much higher proportion of deposits of glacial origin (Major 2009). On top of the slope in the northern fragment of the catchment (OD8), predominant in the upper part of the profile are medium diamictic sands. Below there are sands, mostly fine-grained, interbedded twice with medium diamictic sands, first between 190 and 230 $\mathrm{cm}$ b.g.l. and then between 340 and $390 \mathrm{~cm}$ b.g.l. In the neighbouring profile located in the middle of the slope (OD7), diamictic sands appear only near the land surface. Below are only mediumgrained sands.

In the analogous profile on the other side of the catchment (OD2), the situation is reversed: 
predominant in the near-surface layers are medium-grained sands, while below $160 \mathrm{~cm}$ b.g.l. there are only diamictic sands. In the watershed zone in the southern part the catchment (OD3), in the near-surface layers there are medium diamictic sands alternating with sands and sandy diamicton. All the deposits are medium-grained.

On the northern (OD6) and southern (OD1) sides of the basin bottom, medium-grained sands predominate. The basin bottom (OD4 and OD5) is built of fine-grained deposits: sandy silt which passes into sandy diamicton, and sandy diamicton which turns into sand.

\section{Results and discussion}

The water cycle system in the catchments of basins without outlets in a postglacial area is a carrier of dissolved matter and determines their operation. The effects are reflected in their soil covers and lithology.

Predominant in the catchment of the closed evapotranspiration basin under study are sand deposits, especially medium-grained sands. Much less abundant are diamictic sands and sandy diamictons, which dominate in the bottom of the kettle pond and in near-surface layers in the northern and southern parts of the catchment. Sporadically one can find silts in the basin centre and in the western part of the catchment.

The mean grain diameter $(\mathrm{Mz})$ generally informs about an average grain diameter (arithmetic mean) in the given distribution and about the dynamics of the sedimentary environment (Racinowski et al. 2001). In the W-E cross-section, coefficient $\mathrm{Mz}$ for the entire population sampled from the bore-holes ranged between -0.62 and 6.35 on the phi scale, with a decided majority of its values falling in the interval of $1-3$, which is mostly connected with saltation transport of the material. Most $\mathrm{Mz}$ figures above 3 on the phi scale were recorded near the bottom of the depression, which is indicative of the movement of the finest material in the form of a suspension towards its central part. In turn, the lowest mean grain diameter values, below 1 on the phi scale, were noted at site P6 on top of the slope in the eastern part where the coarsest material can be found. This must also have been the area where material was transported by traction. A similar spatial distribution of $\mathrm{Mz}$ values was recorded in the N-S cross-section, where those figures ranged from 1.6 to 5.17. The highest were found near the basin bottom, and in the other localities Mz figures were in the interval of 1-3 on the phi scale, which again supports the finding that the dominant mode of material transport in the catchment of this closed basin was saltation. Standard deviation $(\delta)$ characterises the scatter of elements in a given grain-size distribution, i.e. it tells whether the grain sizes of a deposit are highly or poorly concentrated around the mean (Racinowski et al. 2001). Standard deviation figures are a measure of sorting of the material and define transport dynamics in the environment. When analysing the results, it was found that in both the W-E and N-S cross-sections the situation was very similar. The deposits predominant at nearly all the sites were poorly and very poorly sorted $(\delta 1.0-2.0$ and $\delta$ $2.0-4.0$ on the phi scale, respectively). There was little medium-sorted deposit ( $\delta$ 0.5-1.0), and most of it could be found at sites OD6 and OD1, or near the bottom in the $\mathrm{N}$ and $\mathrm{S}$ parts of the basin.

Skewness (asymmetry) indicates whether a grain-size distribution is symmetrical about the modal value, or whether the segments of the density curve slope at different angles towards the coarser and the finer diameters (Racinowski et al. 2001). In other words, the skewness index (Sk) is a measure of asymmetry with respect to the normal distribution and assumes positive or negative values. In the catchment under study, there is no steady tendency in the closed evapotranspiration basin. In both cross-sections, in all the bore-holes the index assumes positive values which indicate that in the given deposit the finer fraction predominates over the maximumfrequency fraction, and negative values when the coarse-grained fraction predominates over the maximum-frequency one. Positive Sk figures suggest conditions favourable to rubble deposition, or that rubble is in the mass transit stage. In turn, negative Sk values are indicative of rubble in a stage of selective wash (deflation), or that there are tendencies to redeposition of the bottom material (Racinowski et al. 2001).

Kurtosis (Kg), or a measure of peakedness, explains to what extent the central part of a grainsize distribution departs from the normal distri- 
bution: whether it is flatter or more peaked than the normal distribution (Racinowski et al. 2001). The flattened (platykurtic) grain-size distribution dominant in bore-holes P1 and P6 on the eastern side of the catchment of the depression along the W-E cross-section and in bore-hole OD6 in its bottom on the northern side (along the N-S crosssection) shows a low degree of kurtosis, with $\mathrm{Kg}$ figures under 0.9. This distribution speaks of multifractionality of the deposits and substantial changes in environment energy. It also indicates a high level of saturation of the sedimentary environment with mineral material. In the remaining localities the kurtosis figures are higher. It can be assumed that the higher the $\mathrm{Kg}$ values, the more uniform the dynamic conditions in the given sedimentary environment used to be. The normal distribution (mesokurtic, with $\mathrm{Kg}$ values from 0.9 to 1.1) represents a level of saturation with mineral material typical of the given conditions of the sedimentary environment. It can be found at site OD4 in the bottom of the closed basin and in bore-holes P3 and P5 in the western part of its catchment (the W-E profile). However, the predominant grain-size distribution is a peaked one (leptokurtic, with a high degree of kurtosis, $\mathrm{Kg}$ values in excess of 1.1), which means that the deposit has accumulated in uniform dynamic conditions. It is also indicative of a deficit of bedload in the given stream environment. Such material is in transit, is being transported or deposited in a selective way. The leptokurtic distribution predominates in the W-E profile at points P2, P3 and $\mathrm{P} 4$, and its share in bore-hole P5 is considerable. In turn, in the N-S profile this type of distribution predominates at points OD1, OD2 and OD5.

An important stage of work on the identification of deposits of varying genesis was a comparison of the mean grain diameters $(\mathrm{Mz})$ against standard deviation ( $\delta$ ). Mycielska-Dowgiałło (1995) distinguishes three tendencies in the pattern of point fields. The first, most popular, is one where $\mathrm{Mz}$ indices decline as standard deviation figures grow. In the second pattern both indices increase, and in the third the mean grain diameters vary, while the sorting indices $\delta$ are similar. On the basis of the results obtained, it can be concluded that the first type occurs in the W-E profile on top of the slopes (bore-holes P5 and P6) and in the middle of the slope in the eastern part (P4), and in the N-S profile, at mid-slope site OD2 in the southern part of the catchment. This pattern is characteristic of environments of varying dynamics and high variability of the force transporting the deposit. The remaining sites fit the third pattern best, with its different $\mathrm{Mz}$ values and similar $\delta$ indices. It seems to be typical of environments of low dynamics and low variability of the force transporting the deposit, like the closed depression studied. The process that predominates here is sorting, while the (water or air) flow regime does not supply poorly sorted deposit from suspension (Mycielska-Dowgiałło 1995).

Such lithological differences are responsible for the various rates of the water cycle recorded in the particular parts of the study area. On the slopes surrounding the kettle pond, the lithology favours a faster response to precipitation and accelerates the water-circulation rate. In the bottom of the basin, in turn, it slows down the circulation and favours water retention.

\section{Final remarks}

On the basis of the fieldwork conducted and the results obtained, the following final remarks can be formulated:

1. Basins without outlets are found in abundance in West Pomerania, they occupy a substantial proportion of the area, and display great lithological diversity.

2. The differences in the lithology in the upper Parsęta catchment result from the processes of areal deglaciation during the Vistulian Glaciation. The largest area is occupied here by brown morainic tills, sometimes very high in sand content. Sands and gravels of fluvioglacial origin predominate in the north-eastern and middle parts of the catchment, while tills are much less frequent. In the lower reaches of the upper Parsęta one can meet alluvial deposits as well as stratified sands and gravels of older terrace levels. In the Parsęta headwater area there are peats and carbonate gyttja.

3. Predominant in the lithology of the majority of closed basins in the upper Parsęta catchment are fine diamictic sands which pass into sandy diamicton at a depth of $100 \mathrm{~cm}$, followed by 
medium diamictic sands which change into fine sands at depths of 50 and $100 \mathrm{~cm}$, and massive diamictic sands transforming into sandy diamicton at $100 \mathrm{~cm}$.

4. Predominant in the catchment of the closed evapotranspiration basin examined are sand deposits, especially medium-grained sands. Much less abundant are diamictic sands and sandy diamictons, which dominate in the bottom of the kettle pond and near-surface layers in the northern and southern parts of the catchment. Sporadically one can find silts in the basin centre and in the western part of its catchment.

5. The Mz coefficient for all the samples taken from the bore-holes ranged from -0.62 to 6.35 on the phi scale, with a decided majority of its values falling in the interval of $1-3$, which is mostly connected with saltation transport of the material.

6. Standard deviation figures show that the deposit predominating at nearly all the sites is poorly and very poorly sorted. There is little medium-sorted deposit.

7. The skewness index displays no steady tendency, assuming both positive and negative values.

8. The grain-size distribution predominant in the catchment under study is leptokurtic, which means that the deposit has accumulated in uniform dynamic conditions. In a few localities platykurtic and mesokurtic distributions can also be found.

\section{References}

DRWAL J., 1975. Zagadnienia bezodpływowości na obszarach młodoglacjalnych (Issues of the absence of an outlet in postglacial areas). Zeszyty Naukukowe Wydziatu Biologii $i$ Nauk o Ziemi Uniwersytetu Gdańskiego, Geografia 3: 7-26.

DzięcioŁowski W. (ed.), 1980. Ćwiczenia z gleboznawstwa (Soil science exercises). Skrypty Akademii Rolniczej w Poznaniu.

FolK R.L. \& WARD W.C., 1957. Brazos River bar: A study in the significance of grain size parameters. Joural. of Sedimentary Petrology 27: 3-26.

KARCZEWSKI A., 1985. Spatial arrangement of morainic plateau levels of the northern sloping surface in Pomerania as a result of varying deglaciation. Quaestiones Geographicae Special Issue 1: 99-107.

KARCZEWSKI A., 1989. Morfogeneza strefy marginalnej fazy pomorskiej na obszarze lobu Parsęty w vistulianie (Pomorze Środkowe) (Morphogenesis of the marginal zone of the Pomeranian Stage in the area of the Parseta lobe in the Vistulian, Central Pomerania). Seria Geografia 44, Wydawnictwo Naukowe UAM, Poznań: 48 p.

KostrZewski A. \& Zwolí́ski Z., 1990. Denudacja chemiczna i mechaniczna w zlewni górnej Parsęty w roku hydrologicznym 1986 (Chemical and mechanical denudation in the upper Parseta catchment in the hydrological year 1986). Dokumentacja Geograficzna 1: 13-30.

KostrZewsKi A. \& ZwolińsKi Z., 1992. Udział denudacji chemicznej i mechanicznej we współczesnym systemie geomorficznym górnej Parsęty (Pomorze Zachodnie) (Contribution of chemical and mechanical denudation to the present-day geomorphic system of the upper Parsęta, West Pomerania). Prace Geograficzne IGPZ PAN 155.

Kostrzewski A., MAZUReK M. \& Zwoliński Z., 1994a. Dynamika transportu fluwialnego górnej Parsęty jako odbicie funkcjonowania systemu zlewni (Dynamics of the fluvial transport of the upper Parsęta as a reflection of the operation of its catchment). Stowarzyszenie Geomorfologów Polskich, Poznań: 165 p.

Kostrzewski A., Mazurek M., TomcZak G. \& Zwoliński Z., 1994b. Geoekosystem jeziora Czarnego, zlewnia górnej Parsęty (Geoecosystem of Lake Czarne, upper Parsęta catchment). In: A. Kostrzewski (ed.), Zintegrowany Monitoring Środowiska Przyrodniczego. Stacja Bazowa Storkowo. Biblioteka Monitoringu Środowiska, Warszawa: 187-211.

Major M., 2009 Charakter i funkcjonowanie zagłębień bezodptywowych w krajobrazie strefy mtodoglacjalnej (Pomorze Zachodnie, górna Parsęta) (Nature and operation of basins without an outlet in the landscape of a postglacial area (West Pomerania, the upper Parseta river). Poznańskie Towarzystwo Przyjaciół Nauk, Poznań.

Miall A.D., 1978. Lithofacies types and vertical profile models in braided river deposits: a summary. In: A.D. Miall (ed.), Fluvial Sedimentology. Canadian Society of Petroleum Geology Memoire 5: 597-604.

MrcielsKa-Dowgialeo E., 1995. Wybrane cechy teksturalne osadów i ich wartość interpretacyjna (Selected textural characteristics of deposits and their interpretative value). In: E. Mycielska-Dowgiałło \& J. Rutkowski (eds), Badania osadów czwartorzędowych. Wybrane metody i interpretacja wyników. Warszawa: 29-105.

Podziat na frakcje i grupy granulometryczne (Division into granulometric fractions and groups), 1998. Polska Norma, PN R-04033.

Racinowski R., SzczypeK T. \& WAch J., 2001. Prezentacja $i$ interpretacja wyników badań uziarnienia osadów czwartorzędowych (Presentation and interpretation of the results of a study of the granulation of Quaternary deposits). Wydawnictwo Uniwersytetu Śląskiego, Katowice. 